Article

\title{
The Experience of Victimisation among Muslim Adolescents in the UK: The Effect of Psychological and Religious Factors
}

\author{
Leslie J. Francis * and Ursula McKenna ${ }^{\mathbb{D}}$ \\ Centre for Education Studies, University of Warwick, Coventry CV4 7AL, UK; u.mckenna@warwick.ac.uk \\ * Correspondence: Leslie.Francis@warwick.ac.uk
}

Received: 21 March 2018; Accepted: 7 August 2018; Published: 10 August 2018

check for updates

\begin{abstract}
This study set out to explore the levels of victimisation experienced by Muslim adolescents in the UK, the extent to which victimisation is conceptualised in religious terms, and the extent to which individual differences in the experience of victimisation is related to personal factors, psychological factors and religious factors. Data provided by 335 13- to 15 -year-old Muslim students from England, Northern Ireland, Scotland and Wales demonstrated that one in four Muslim students $(25 \%)$ reported being bullied because of their religion. These students saw their religious identity as being a more important cause of their victimisation than their ethnicity, their colour, or their name. Male and female Muslim students were equally vulnerable to victimisation. Psychological and religious variables predicted individual differences in vulnerability to victimisation among Muslim students.
\end{abstract}

Keywords: Muslims; victimization; bullying; psychology of religion; empirical theology

\section{Introduction}

\subsection{Intersections of Religions and Ethnicities}

In 2013 the NSPCC and Childline published a report on school age children who had contacted the organization for counselling. The report found that in 2012-2013 over 1400 young people had experienced racist bullying, a 69\% increase on 2011-2012. A common theme was for young people to be called a 'terrorist' or a 'bomber'. A common cry was for these young people 'to go back to where they came from' (NSPCC/Childline 2013, p. 41). This report does not make any mention of the religious background of the young people reporting such incidents or the school sector that such pupils come from although it does highlight that the majority of counselling was requested by 12-15 years olds. However, there would appear to be a growing sense that Muslim students across the UK are suffering from increasing levels of bullying and abuse. For example, recent media have given attention to a rise in verbal and physical attacks against Muslim pupils (Jeory 2016; Milmo 2015). These incidents have been linked, among other things, to the Charlie Hebdo massacre in Paris on 7 January 2015 and to uncertainty arising from the 'Brexit' vote in the UK. Moreover, it has also been claimed that recent UK government initiatives on counter-terrorism have made Muslim students more vulnerable to victimisation. For example, writing in The Guardian, Qurashi (2016) claimed that

It is clear that the Prevent strategy centres on Muslims in the way that it frames the threat of extremism and terrorism. Added to this, the allocation of Prevent funding, which was based on the number of Muslims in a local authority. This explicit targeting demonstrates that Islamophobia is central in shaping how the government (and wider society) define and construct extremism and terrorism as solely Islamic problems. (Qurashi 2016) 
Current anxieties and phobias in relation to immigration and cultural diversity alongside the prevalence of discrimination, harassment and violence against Asians, and Muslims in particular, have been documented over many years. Such documentation has highlighted the close intersections between religions and ethnicities. Given that the vast majority of Muslims in Britain belong to minority ethnic groups, research has shown that they have experienced racial as well as religiously motivated discrimination (Rattansi 1992; Runnymede Trust 1997; Weller et al. 2001; Vertovec 2002; Allen 2005; Anwar 2005; Modood 2012).

That Muslims, in particular, were subject to discrimination and therefore detriment, on the basis of their faith gained attention with the publishing of the Runnymede Trust report, Islamophobia: A challenge for us all (1997). Incidents of discrimination and hostility heightened after the events of 11 September 2001. Allen (2005) discusses racism against Muslims and in particular 'Islamophobia' examining the extent to which it intensified after 11 September 2001. In doing so he discusses the shift from the marker of 'race' to marker of 'religion' as important. Similarly, almost all of the eighty respondents from central and local government that took part in a study by Anwar (2005) expressed a view that discrimination and/or violence were a major problem for Muslims. An over-whelming majority of respondents said that Muslims experienced discrimination in their daily lives. Some of these respondents specifically referred to 'Islamophobia' as the context for the discrimination and one referred to 'Islam as the most hated religion' - hated both by white people and by some other ethnic minorities (Anwar 2005, p. 41).

In reporting incidents of racism experienced by children, Verma et al. (1994) found that Muslim boys reported suffering the highest rates of racism at school. Similar results were found by Archer $(2003,2012)$ who gave attention specifically to British Muslim boys' identities and experiences in relation to schooling. The boys recounted how their daily commute to school required them to negotiate numerous experiences of verbal and physical racism. In one interview transcript, a boy referred to derogatory and racially insulting name-calling (Archer 2003, p. 108), and in another a boy recounted incidents of people throwing eggs at the windows of Asian homes and throwing rubbish in their gardens, younger siblings being intimidated and being beaten up. This boy viewed 'racism as arising from white people's responses to newness, change and arrival of unknown others' (p. 109). Within the school environment, the boys in Archer's study (Archer 2003) described their experiences of racism as mostly linked to physical bullying (often experienced by younger pupils), recounting fights and attacks and emphasizing the physical injuries sustained by those involved (p. 124) and again emphasising the specifically colour-based context of racism through name-calling (p. 13). According to Archer the boys were asserting the 'natural' colour difference between whites and Asians as being a source of conflict. More recently, a resurgence in incidents of racist name-calling has been reported. Hence, Simo Kotecha, a reporter for the BBC radio station Radio 4, said that she was in 'utter shock' after having been called a racially prerogative term adding 'Haven't heard that word here since the 80s' (cited in Jeory 2016).

It would be wrong to assume that all racist bullying is colour-based in terms of white on black. In a study among 30 Asian children aged 8-10 years, Boulton (1995) found the majority of incidents of bullying reported being within, rather than between, ethnic groups. The most frequent bullies were other Asian children from a different ethnic group. Likewise, Eslea and Mukhtar (2000) in attempting to provide a richer understanding of bullying among older Asian school children in Britain explored the experiences of 243 ethnic minority students aged 12-15 years from Hindu, Indian Muslim, and Pakistani backgrounds. Results showed that bullying was widespread and that it was at least as likely to be by other Asian children of a different ethnic group as it was by white children, and it was likely to relate to some religious or cultural difference in terms of clothing worn or language spoken. Hence, Indian Muslims and Pakistanis were most frequently bullied by Hindus. Pakistani boys were also frequently bullied by Indian Muslims. For Indian Muslims the most frequent kind of bullying related to clothing and accessories. For Pakistanis the most frequent bullying was related to language, then food, and then clothing.

According to Archer (2003) racism directed at Muslim boys could also take a more subtle form. Boys in her study described how white boys would be friendly with them at school, but would ignore 
them in public when they were with their friends and families. In Archer's opinion events such as these can be read as illustrative of 'modern' racism, a subtle and barely discernible racism which is in contrast to 'traditional racism' expressed through the display of overt racist views and behaviours (pp. 115-16).

This modern racism was also to be found in relationships between Muslim boys and school staff. According to Archer (2003) the boys did not experience teacher racisms as overt displays of particular attitudes or behaviours. Rather, such racisms were experienced in more subtle ways; 'teachers are racist-you see it in their eyes'; 'they ignore you' or 'just talk over you' (Archer 2003, p. 118). This was also the finding of Bowlby and Lloyd-Evans (2012) who reported that some of the young Muslim boys to whom they talked had experienced low expectations from teachers. They concluded that the stereotypical attitudes of many teachers and career advisors could have a negative impact on the aspirations and attainment of Muslim youth.

Anwar (2005) maintains the need to remain especially sensitive to both structural and cultural racism. Half of the respondents in Anwar's study mentioned some aspects of the education system that go beyond a failure to meet the needs of Muslims, being more actively hostile to Islam, Muslim pupils and their parents. Bullying of Muslim pupils was seen as a problem that schools were failing to tackle adequately with one respondent stating that 'bullying and attacks on Muslims in state schools ... are common' (p. 33). Likewise, as noted by Archer (2003), Muslim boys in her study also drew upon a notion of structural racism, arguing that Asian pupils were collectively disadvantaged by particular school rules and conventions. The perception was voiced that the school was 'unwilling to tackle incidents of racism and would persistently favour white boys, due to its policy of non-intervention, and because issues of pupil violence were rarely treated as issues of racism' (p. 119).

Whilst the work of Archer is focused on Muslim boys, the issues of structural and cultural racism has also been found to affect Muslim girls. In the study by Bowlby and Lloyd-Evans (2012), there was a consensus among both the young male and female Muslims interviewed that some teachers had a stereotypical image of 'young Muslim women' as submissive, uninterested in work and prevented by family or community pressures from pursuing a career. A few respondents in Anwar (2005) study also referred to the stereotyping of Muslim pupils, particularly girls-including an expectation of under achievement.

Whilst Muslim girls, like Muslim boys, may experience stereotyping and low expectations there are also some differences in their experiences. The racism to which they are subjected has been found to be less about colour and more to do with the wearing of visible outward symbols of their faith which has led to an increase in fear and perceived vulnerability in schools and public spaces. As noted by Bowlby and Lloyd-Evans (2012), recent political controversy over the rights of Muslim women to wear the veil has heightened sensitivities around dress and appearance. They cite the work of Hopkins and Patel (2006) who found that women who were visibly Muslim were more likely to report discrimination in the labour market than those who adopted a more Western appearance when they were in public spaces. Likewise, the research of Anwar and Shah (2000) found Muslim girls had been excluded from schools because they wanted to wear headscarves. More recently, Jeory (2016) cites the anti-Muslim hate monitoring group Tell MAMA who found British Muslims were suffering an 'explosion' in faith-based hatred with many women afraid to conduct their daily lives. Its survey found the effect on Muslim women-particularly those wearing any Islamic clothing-was now so grave that many were being prevented from conducting 'day to day activities'. It said 61 per cent of victims in the cases it recorded involved women and of those, 75 per cent were clearly identifiable as Muslim, for example due to their headscarves or veils.

This literature raises two fundamental research questions that form the starting point for the present analyses. The first research question concerns the extent to which self-identified Muslim students in the UK experience victimisation or bullying. The second research question concerns the extent to which they attribute such victimisation or bullying to their religious identity, or to other 
features that may set them apart, including their race or colour, their family origin within another country, their language, their clothes, and their name.

These two fundamental research questions, however, need to be contextualised within two other bodies of literature. First, self-assigned religious affiliation (in this case as Muslim) only accesses one component of religious identity. The extent to which individual Muslim students may experience victimisation may well be related to the broader nature of their religious identity. It would be wise to take broader discussions within the social scientific study of religion into account in nuancing the dimensions of religiosity. Second, both the literature on individual differences in religiosity and the literature on individual differences in the experience of victimisation have demonstrated the importance of personality theories. It would be wise to take these literatures into account as well.

\subsection{Multiple Indices of Religion}

The social scientific study of religion offers a highly nuanced understanding of religious people that includes the notions of self-assigned religious affiliation, public practice like worship attendance, private practice like personal prayer and reading sacred scripture, participation in religious groups, religious belief, and religious attitudes. Established research within the social scientific study of religion has refined and evaluated each of these concepts.

Self-assigned religious affiliation is core to the present study since the participants have been identified as Muslim by the way in which they responded to the question 'What is your religion?' The inclusion of religious affiliation in the civic census, as introduced within England, Wales and Scotland for the first time in 2001, conceptualises this marker as a matter of public and social significance, an indicator of identity like sex and ethnicity (Francis 2003). The predictive power of religious affiliation in areas of personal and social values among young people has been documented by Francis (2008a, 2008b).

By itself, however, self-assigned religious affiliation may be a precarious indicator of religious identity. Alongside the simple question about affiliation, some scientific investigations have included a further question concerning the importance of religious identity. This question helps to distinguish between those for whom their religious affiliation may be a relatively trivial matter and those for whom it may be more central to their personal identity.

Public practice, like worship attendance, has been routinely collected in surveys such as the British Social Attitudes Survey. The predictive power of church attendance in areas of personal and social values among young people has been well documented by Francis (2001) in The Values Debate, and more widely by Gill (1999) in Churchgoing and Christian ethics.

There has been a long-established interest within the psychology of religion concerned with exploring the correlates of personal prayer, as reviewed in such studies as Brown (1994), Francis and Astley (2001) and Spilka and Ladd (2013). The predictive power of personal prayer in areas of personal and social values among young people has been documented by Francis and Penny (2016).

Less attention has been given within the social scientific study of religion to exploring the correlates of scripture reading. However, some interest has been shown in this field among young people in particular, including studies reported by Francis $(2000,2002)$ exploring the connection between scripture reading and issues like purpose in life and alcohol-related attitudes and behaviours.

Participation in religious groups, other than through church attendance, may be regarded as of particular significance for young people. For example, in a Christian context attendance at Sunday school or youth nurture group may be regarded as particularly influential. This issue was examined from an empirical perspective by Francis et al. (1991).

Religious belief or belief in God has also been brought to the fore in a number of scientific enquiries concerning the correlates of individual differences in religiosity. For example, Francis et al. (2013) recently examined the difference in social and personal values held by young atheists (who do not believe in God) and by young theists (who do believe in God). 
Religious attitudes are concerned with the affective dimension of religion. In an early study, Francis (1978) argued that the attitudinal dimension of religion may get closest to the heart of an individual's religiosity, and as a consequence offer the strongest prediction of the correlates, consequences and antecedents of individual differences in religiosity. Following that original publication, a significant literature has emerged employing a family of instruments designed to address this research question across the major faith traditions (see Francis 2009), including the Astley-Francis Scale of Attitude toward Theistic Belief (Astley et al. 2012).

This literature raises the research question concerning the extent to which these different components of religious identity may be related to the extent to which individual Muslim students may experience victimisation. Are there specific ways of being religious that may enhance vulnerability?

\subsection{Personal and Psychological Factors}

Both the research literatures on individual differences in religiosity and on individual differences in victimisation have noted the key role of personality. Particularly fruitful in this latter respect has been the dimensional model of personality proposed by Eysenck and Eysenck (1991). Eysenck's dimensional model of personality maintains that individual differences in personality can be most adequately and economically summarised in terms of three higher order orthogonal dimensions (extraversion, neuroticism, and psychoticism). This model also takes the view that neurotic and psychotic disorders are not discontinuous from normal personality but occupy the extreme end of two different continua which describe individual differences in normal personality. Eysenck's three-dimensional model of personality has been operationalised in a series of instruments designed for use among both adults and young people, including the Eysenck Personality Questionnaire (Eysenck and Eysenck 1975), the Eysenck Personality Questionnaire Revised (Eysenck et al. 1985) and the Eysenck Personality Scales (Eysenck and Eysenck 1991).

The emerging importance of the Eysenckian three-dimesional model of personality within the empirical psychology of religion was noted by Beit-Hallahmi and Argyle (1997) in their review of the field. While Argyle (1958) original review concluded that there was insufficient empirical evidence to link religiosity with personality, re-visiting the field forty years later, Beit-Hallahmi and Argyle (1997) concluded that a sufficient body of research had accrued to revise their earlier evaluation. Empirical studies within the psychology of religion employing Eysenck's dimensional model of personality have consistently reported an inverse association between psychoticism scores and religiosity, as crystallised by Francis (1992) and confirmed by more recent studies, including Francis et al. (2007); Francis et al. (2008) and Francis and Hermans (2009). Alongside personality, sex and age have also been identified as core predictors of individual differences in religiosity (see Kay and Francis 1996; Francis 1997; Francis and Penny 2014).

A small but growing international literature over the past thirty years has studied bullying and victimisation in relation to personality. Early research undertaken with children and adolescents suggested that victims of bullying scored higher than non-victims in neuroticism (or low emotional stability) (Slee and Rigby 1993; Francis and Jones 1994; Mynard and Joseph 1997; Hodges and Perry 1999; Tani et al. 2003). Victims in some of these studies also scored low on extraversion when using the Eysenck and Eysenck (1975) personality model (Mynard and Joseph 1997). More recent studies have found similar results (De Bolle and Tackett 2013; Kodžopeljić et al. 2014; Mitsopoulou and Giovazolias 2015). Kodžopeljić et al. (2014), in a Serbian study, found that victims scored highest on neuroticism, and in a Belgium study, De Bolle and Tackett (2013) showed that children with low emotional stability were more prone to both bullying and victimisation.

Mitsopoulou and Giovazolias (2015) conducted a literature review and meta-analysis, drawing on much of the research published in this area over the past 30 years, exploring the relationship between personality, bullying, and victimisation. Drawing on the Big Five Factors model (Costa and McCrae 1985), the strongest associations were with neuroticism and conscientiousness. Moreover, this link between personality and susceptibility to victimisation and bullying has been shown to 
continue into the world of work. Research by Milam et al. (2009) found that individuals high in neuroticism experienced more incivility than their colleagues in the workplace. Likewise, Nielsen and Knardahl (2015) found that neuroticism significantly predicted subsequent bullying in analyses of direct associations between personality and victimisation.

These literatures raise the research question concerning the extent to which these personal factors (sex and age) and psychological factors (extraversion, neuroticism and psychoticism) may interact with religious factors in predicting the vulnerability of individual Muslim students to victimisation. Are females or males more vulnerable? How much does personality really play a part?

\subsection{Research Aims}

Against this background, the present study was designed to draw on data provided by the Young People's Attitudes to Religious Diversity Project in order to explore the levels of victimisation experienced by Muslim students in the UK. The Young People's Attitudes toward Religious Diversity Project (funded within the ESRC/AHRC Religion and Society Programme) was set up to map the attitudes of 13- to 16-year-old students across the four nations of the UK, employing both qualitative and quantitative methodologies. The quantitative stream was shaped with a particular concern to explore the correlates, antecedents and consequences of individual difference in young people's attitudes toward religious diversity (see Francis et al. 2012a, 2012b, 2013, 2014a, 2014b, 2015, 2017; Francis and Village 2014, 2015). The present study addressed four specific research aims to these data.

The first research aim was to identify the levels of victimisation experienced by these students and the specific triggers to which they attribute the cause of their victimisation. Drawing on extant literature, the following seven triggers were included in the survey: race, country of origin, language, religion, clothes, name, and friends. Just how salient is religious identity in the minds of young Muslims in attributing the cause of experienced victimisation?

The second research aim was to test whether the seven triggers of victimisation cohere to generate a psychometrically sound measure of the experience of victimisation appropriate for scientific use among Muslim students in the UK. The third research aim was to explore the predictive power of two personal variables (sex and age) and three psychological variables (extraversion, neuroticism and psychoticism) in predicting individual differences in the experience of victimisation among Muslim students. The fourth research aim was to explore the predictive power of seven religious variables (religious attendance, personal prayer, scripture reading, belief in God, importance attributed to religious identity, attitude toward religion, and religious classes outside school) in predicting individual differences in the experience of victimisation among Muslim students, when the personal variables and the psychological variables were also in the model.

\section{Method}

\subsection{Procedure}

The Young People's Attitude to Religious Diversity Project set out to obtain responses from at least 2000 13- to 15-year-old students attending state-maintained schools in each of five parts of the UK: England, Northern Ireland, Scotland, Wales and London. In each nation half of the students were recruited from schools with a religious character (Anglican, Catholic, or joint Anglican and Catholic) and half from schools without a religious character. Within the participating schools, questionnaires were administered by religious education teachers under examination-like conditions. Students were assured of anonymity and confidentiality and given the option not to participate in the project. All told 11,809 students participated in the project.

\subsection{Participants}

The present analyses were conducted on the sub-sample from the Young People's Attitude to Religious Diversity Project of the 335 participants who self-identified as Muslim and who also 
self-identified as male or female. In terms of sex and age, $47 \%$ were male and $53 \%$ were female; $57 \%$ were in Year nine and $43 \%$ were in Year ten.

\subsection{Measures}

Experience of victimisation was assessed by the 7-item Experience of Victimisation Index (EVI) developed specifically for this study. Each item was assessed on a five-point Likert scale: disagree strongly (1), disagree (2), not certain (3), agree (4), and agree strongly (5).

Personality was assessed by the abbreviated version of the Junior Eysenck Personality Questionnaire Revised (JEPQR-A) developed by Francis (1996) who reported the following Cronbach alpha coefficients: extraversion $=.66$; neuroticism $=.70$; psychoticism $=.61$; lie scale $=.57$.

Sex and age were recorded as dichotomous variables: male (1) and female (2); Year nine (1) and Year ten (2).

Religious identity was assessed by the question 'My religious identity is important to me'. Responses were assessed on a five-point scale: disagree strongly (1), disagree (2), not certain (3), agree (4), and agree strongly (5).

Religious attendance was assessed by the question 'Apart from special occasions (like weddings) how often do you attend a religious worship service (e.g., at a church, mosque or synagogue)?'. Responses were recorded on a seven-point scale: never (1), sometimes (2), at least once a year (3), at least six times a year (4), at least once a month (5), nearly every week (6), and several times a week (7).

Personal prayer was assessed by the question 'How often do you pray in your home or by yourself?'. Responses were recorded on a five-point scale: never (1), occasionally (2), and at least once a month (3), at least once a week (4), and nearly every day (5).

Scripture reading was assessed by the question 'How often do you read holy scripture (e.g., The Bible, Qur'an, Torah)?'. Responses were recorded on a five-point scale: never (1), occasionally (2), at least once a month (3), at least once a week (4), and nearly every day (5).

Attendance at religious classes was assessed by the question 'Have you attended any religious classes outside school (like Sunday School or Madrasah)?'. Responses were recorded as a dichotomous variable: no (1), yes (2).

Belief in God was assessed by the statement 'I believe in God'. Responses were recorded on a five-point scale: disagree strongly (1), disagree (2), not certain (3), agree (4), and agree strongly (5).

Attitude toward religion was assessed by the seven-item Astley-Francis Scale of Attitude toward Theistic Faith (Astley et al. 2012). An example item is: 'Prayer helps me a lot'. Responses to each item were recorded on a five-point scale: disagree strongly (1), disagree (2), not certain (3), agree (4), and agree strongly (5).

\subsection{Analysis}

The data were analysed using the SPSS statistical package, drawing on the frequency, correlation, factor, reliability and regression routines. The regression routine employed fixed order entry so that the four sets of variables (personal, psychological, religious, and theological) were structured incrementally in such a way that personal variables are taken into account first, followed by psychological variables. This sequence allows the additional effects of religious variables (entered at step three) to be observed.

\section{Results and Discussion}

The religious and theological variables included in the survey offer a thorough profile of the religiosity of the participants. In terms of frequency of worship attendance, $12 \%$ reported never attending, $42 \%$ attended less than six times a year, $8 \%$ at least six times a year, $10 \%$ at least once a month, and $18 \%$ every week and $10 \%$ several times a week. In terms of frequency of personal prayer, $10 \%$ reported never praying, $22 \%$ occasionally, $5 \%$ at least once a month, $8 \%$ at least once a week, and $56 \%$ every day. In terms of frequency of reading holy scripture, $10 \%$ reported never doing so, $30 \%$ occasionally, $8 \%$ at least once a month, $26 \%$ at least once a week, and $26 \%$ every day. In terms of 
attendance at religious classes outside school, $74 \%$ reported having done so, and $27 \%$ as never having done so. In terms of belief in God, $89 \%$ agreed or agreed strongly that they believed in God, $8 \%$ were not certain whether they believed in God, and $4 \%$ disagreed or disagreed strongly that they believed in God. In terms of religious identity, 55\% agreed strongly that their religious identity was important to them, $29 \%$ agreed, $8 \%$ were uncertain, $3 \%$ disagreed, and $5 \%$ disagreed strongly.

The first step in data analysis explored the scale properties of the Experience of Victimisation Index in terms of the correlations between the individual items and the sum of the other items, and in terms of the item endorsement on the sum of the 'agree' and 'agree strongly' responses. These data, presented in Table 1, demonstrate a good level of internal consistency reliability with an alpha coefficient of .90 and correlations between individual items and the sum of the other six items ranging between .57 and .77. The percentage endorsement of the individual items demonstrate considerable variation in levels of endorsement given to the various factors triggering the bullying experienced by these Muslim students. The most important trigger for being bullied emerged as their religious identity. One in four of these Muslim students claimed to be bullied because of their religion (25\%). Then the following factors were noted as triggers of bullying in descending order of frequency: race (23\%), coming from another country $(17 \%)$, their name $(15 \%)$, who their friends were $(10 \%)$, their language $(8 \%)$ and their clothes ( $8 \%)$.

Table 1. Experience of Victimisation Index (EVI): Scale properties.

\begin{tabular}{lll}
\hline & $\boldsymbol{r}$ & $\mathbf{\%}$ \\
\hline I am bullied because of who my friends are & .57 & 10 \\
I am bullied because of my race or colour & .76 & 23 \\
I am bullied because of my religion & .76 & 25 \\
I am bullied because of my name & .68 & 15 \\
I am bullied because of my language & .77 & 8 \\
I am bullied because of my clothes & .70 & 8 \\
I am bullied because my family comes from another country & .72 & 17 \\
Alpha coefficient & .90 & \\
\hline
\end{tabular}

Note: \% = sum of agree and agree strongly responses. $r=$ correlation between individual item and sum of other ten items.

The second step in data analysis explored the scale properties of the five scales employed in the analyses in terms of the alpha coefficient (Cronbach 1951) and in terms of the means and standard deviations. Table 2 demonstrates that the Scale of Attitude toward Theistic Faith, the Experience of Victimisation Index, achieved a high level of internal consistency reliability with an alpha coefficient of .90. The neuroticism scale achieved an alpha coefficient in excess of the threshold of .65 proposed by DeVellis (2003). Lower alpha coefficients were achieved by the psychoticism scale and the extraversion scale.

Table 2. Scale Properties.

\begin{tabular}{lllllll}
\hline & N Items & $\boldsymbol{\alpha}$ & $\boldsymbol{M}$ & $\boldsymbol{S D}$ & Low & High \\
\hline Experience of victimisation & 7 & .90 & 13.44 & 6.88 & 7 & 35 \\
Attitude toward Theistic Faith & 7 & .90 & 29.30 & 5.92 & 7 & 35 \\
Extraversion & 6 & .57 & 4.63 & 1.48 & 0 & 6 \\
Neuroticism & 6 & .68 & 3.23 & 1.80 & 0 & 6 \\
Psychoticism & 6 & .63 & 1.05 & 1.32 & 0 & 6 \\
\hline
\end{tabular}

The third step in data analysis explored the correlations between both personal factors (sex and age) and psychological factors (psychoticism, neuroticism and extraversion) and the religious variables, and the measure of experience of victimisation employed in the analyses. These data are presented in Table 3. 
Regarding sex differences, these data demonstrate that among Muslim youth, males are more likely than females to attend religious worship, to engage in personal prayer, and to attend religious classes outside school. This is quite distinct from the general finding in Christian and post-Christian contexts in which woman report higher levels of religious worship attendance and personal prayer than men (Francis 1997; Francis and Penny 2014). On the other hand, there were no significant sex differences reported in respect of frequency of scripture reading, belief in God, attitude toward theistic faith, or importance of religious identity.

The correlations with personality variables presented in Table 3 demonstrate that in terms of the religious variables, psychoticism provides stronger prediction of individual differences than either extraversion or neuroticism. This finding is consistent with the general conclusion within the psychology of religion, as recorded historically by Francis (1992). There are significant negative correlations between psychoticism scores and belief in God, attitude toward theistic faith and importance of religious identity. Extraversion scores also predict individual differences in respect of three of the religious variables. Introverts record significantly higher scores of personal prayer, belief in God and importance of religious identity. There were no significant associations between neuroticism scores and any of the religious variables.

Finally, Table 3 demonstrates that psychological variables are implicated with individual differences in experience of victimisation. Muslim students who record higher scores on the neuroticism scale and lower scores on the extraversion scale report higher levels of experience of victimisation. On the other hand, there were no significant correlations between experience of victimisation and psychoticism scores or the personal variables (age and sex).

Table 3. Correlations with personal and psychological variables.

\begin{tabular}{llllll}
\hline & Sex & Age & P & N & E \\
\hline Religious variables & & & & & \\
$\quad$ Religious worship & $-.28^{* * *}$ & .01 & .02 & -.01 & -.11 \\
$\quad$ Personal prayer & $-.13^{* *}$ & -.05 & -.07 & -.05 & $-.16^{* *}$ \\
$\quad$ Scripture reading & -.09 & $-.19^{* * *}$ & -.10 & -.03 & -.09 \\
$\quad$ Belief in God & .02 & -.03 & $-.28^{* * *}$ & .01 & $-.15^{* *}$ \\
$\quad$ Attitude toward Theistic & .01 & -.04 & $-.28^{* * *}$ & .06 & -.11 \\
Faith & $-.18^{* * *}$ & .00 & .02 & .00 & -.07 \\
$\quad$ Religious classes & -.05 & -.01 & $-.22^{* * *}$ & .07 & $-.16^{* *}$ \\
$\quad$ Importance of religious & -00 & & & \\
identity & & & .11 & $.31^{* * *}$ & $-.13^{*}$ \\
Experience of victimisation & .01 & .08 & &
\end{tabular}

Note: ${ }^{*} p<0.05 ;{ }^{* *} p<0.01 ;{ }^{* * *} p<0.001$.

The fourth step in data analysis explored the interconnection between experience of victimisation, and the seven religious variables. These data, presented in Table 4, demonstrate two main points. First, all seven religious variables are significantly intercorrelated. For example, within this context personal prayer predicts greater levels of worship attendance, scripture reading and attendance at religious classes outside school, higher levels of belief in God, greater importance attributed to religious identity and more positive attitudes toward religion. Similarly, a positive attitude toward theistic faith predicts greater levels of worship attendance, personal prayer, scripture reading, and attendance at religious classes outside school, higher levels of belief in God, and greater importance attributed to religious identity. Second, two of the seven religious variables function as significant predictors of a higher level of experience of victimisation. Students who practise higher levels of worship attendance and who attend religious classes outside school report higher levels of experience of victimisation. 
Table 4. Correlation matrix for religious variables and experience of victimisation.

\begin{tabular}{|c|c|c|c|c|c|c|c|}
\hline & RI & WA & PP & SR & BG & AT & RC \\
\hline Victimisation & .06 & $.15^{* *}$ & .02 & -.01 & -.08 & .02 & $.12 *$ \\
\hline Religious classes & $.17^{* *}$ & $.29^{* * *}$ & $.27^{* * *}$ & $.35^{* * *}$ & $.13^{* *}$ & $.14^{* *}$ & \\
\hline Theistic faith & $.57^{* * *}$ & $.28^{* * *}$ & $.41^{* * *}$ & $.43^{* * *}$ & $.52 * * *$ & & \\
\hline Belief in God & $.50 * * *$ & $.16^{* *}$ & $.32 * * *$ & $.30^{* * *}$ & & & \\
\hline Scripture reading & $.37^{* * *}$ & $.42^{* * *}$ & $.61^{* * *}$ & & & & \\
\hline Personal prayer & $.40^{* * *}$ & $.42^{* * *}$ & & & & & \\
\hline Worship attendance & $.27^{* * *}$ & & & & & & \\
\hline
\end{tabular}

Note: $\mathrm{RC}=$ Religious classes; $\mathrm{AT}=$ Attitude toward theistic faith; $\mathrm{BG}=$ Belief in God; $\mathrm{SR}=$ Scripture reading; $\mathrm{PP}=$ Personal prayer; $\mathrm{WA}=$ Worship attendance; $\mathrm{RI}=$ Importance of religious identity. ${ }^{*} p<0.05 ;{ }^{* *} p<0.01$; $* * * p<0.001$.

In view of these complex patterns of intercorrelations between the variables, the fifth step in data analysis proposes a sequence of regression models that take experience of victimisation as the dependent variable (see Table 5). Model one examines the effect of the personal factors (sex and age) on experience of victimisation. The beta weights confirm the non-significance of both sex and age.

Model two adds the psychological factors (psychoticism, neuroticism, and extraversion). The beta weights confirm that neuroticism scores exert the largest effect (with high scores being associated with a higher level of experience of victimisation). Once neuroticism scores have been taken into account, neither psychoticism scores nor extraversion scores (as initially suggested by the correlation matrix) are significantly associated with scores of experience of victimisation.

Table 5. Regression models on experience of victimisation.

\begin{tabular}{|c|c|c|c|}
\hline & Model 1 & Model 2 & Model 3 \\
\hline \multicolumn{4}{|l|}{ Personal factors } \\
\hline Sex & -.02 & -.07 & -.01 \\
\hline Age & .07 & .07 & .06 \\
\hline \multicolumn{4}{|l|}{ Psychological factors } \\
\hline Extraversion & & -.10 & -.10 \\
\hline Neuroticism & & $.29 * * *$ & $.27^{* * *}$ \\
\hline Psychoticism & & .13 & .11 \\
\hline \multicolumn{4}{|l|}{ Religious factors } \\
\hline Religious identity & & & .09 \\
\hline Worship attendance & & & $.15^{*}$ \\
\hline Scripture reading & & & -.11 \\
\hline Personal prayer & & & .00 \\
\hline Belief in God & & & -.12 \\
\hline Attitude toward Theistic Faith & & & .03 \\
\hline Religious classes & & & .10 \\
\hline Total $r^{2}$ & .005 & .128 & .171 \\
\hline
\end{tabular}

Model three adds the religious factors offered within the framework of the social scientific study of religion. The beta weights show that only the frequency of worship attendance is significantly associated with experience of victimisation. Young Muslims who practise frequent worship attendance report higher levels of experience of victimisation. Once frequency of worship attendance has been taken into account, attendance at religious classes outside school is not significant (as initially suggested by the correlation matrix). 


\section{Conclusions}

This study drew on data provided by the Young People's Attitudes to Religious Diversity Project in order to explore the levels of victimisation experienced by Muslim students in the UK. Four specific research aims were addressed by these data.

The first research aim was to identify the level of victimisation experienced by these Muslim students and the specific triggers to which they attribute the cause of their victimisation, distinguishing among the seven factors of race, country of origin, language, religion, clothes, names, and friends. The data identified religion as the highest perceived trigger of victimisation with $25 \%$ of Muslim students saying that they are bullied because if their religion. As these young Muslim students construe their experience of life in the UK they see their religion as a greater source of threat to them than their race or language.

The second research aim was to test whether the seven triggers of victimisation cohere to generate a psychometrically sound measure of the experience of victimisation appropriate for scientific use among Muslim students in the UK. The data demonstrated a good level of internal consistency reliability for the seven-item instrument proposed as the Experience of Victimisation Index (EMI). This finding demonstrates that young Muslims perceive the vulnerability marked by their religion to be closely associated with the other six factors rather than to be operating independently. This finding also confirms the legitimacy of employing the summated scale score (with a score range of 7 to 35) in order to explore more fully the correlates of individual differences in perceptions of victimisation.

The third research aim was to explore the predictive power of two personal variables (sex and age) and three psychological variables (extraversion, neuroticism, and psychoticism) in predicting individual differences in the experience of victimisation among Muslim students. The data demonstrates that there were no significant sex differences. Male and female Muslim students were equally exposed to bullying. Neither were there significant age differences within the limited age range surveyed by the current study. Muslim students in Year nine (13- to 15-years of age) and Muslim students in Year ten (14- to 15-years of age) were equally exposed to bullying. The main finding from the three personality variables concerns the significant positive association between neuroticism scores and the experience of victimisation, as identified by both the bivariate correlation coefficients and the regression model. This finding is consistent with the body of earlier research that associates higher levels of anxiety (as reflected within the Eysenckian neuroticism scale) with greater exposure to victimisation and bullying (see Francis and Jones 1994).

The fourth research aim (the core aim of the analyses) was to explore the predictive power of seven religious variables (religious attendance, personal prayer, scripture reading, belief in God, importance ascribed to religious identity, attitude toward religion, and attendance at religious classes outside school) in predicting individual differences in the experience of victimisation among Muslim students, after controlling for the effects of personal variables and psychological variables. The data demonstrate that among Muslim students frequency of worship attendance is the key indicator (among the seven religious factors) of greater vulnerability to victimisation. It is those Muslim students who are seen to take their religious faith seriously through participation in worship attendance who experience higher levels of victimisation and bullying.

The findings from this study carry implications for educational theory and for educational practice. The recognition that one in every four Muslim students (25\%) reported that they are bullied because of their religion emphasizes the important role of religious education in dealing with topics concerning difference, diversity and inclusion. The recognition that individual differences both in personality (neuroticism) and in religious practice (worship attendance) increase the vulnerability of Muslim students experiencing bullying because of their religion alerts pastoral care networks within schools to identifying students most at risk in this way.

The limitations with the present study are clearly defined by four factors. First, the dependent variable (concerned with experience of victimisation) has been shaped by one specific operationalised form. Future research would be well advised to develop a wider battery of cognate measures. Second, 
the key religious variable identified by the findings (concerned with frequency of worship attendance) remains a relatively blunt measure, especially when used among a mixed sample of male and female Muslims. Future research would be well advised to explore a wider and more nuanced set of measures to operationalise more fully Muslim students' experience of worship attendance. Third, these analyses have been conducted among a relatively small sample of Muslim students. Among 11,809 participants within the Young People's Attitude toward Religious Diversity Project recruited from across the four nations of the UK, just 335 self-identified as Muslim and also as male or female. Future research concerned with attitude toward religious diversity among young people within the UK would be well advised specifically to target schools within the state-maintained sector in which there were larger numbers of Muslim students. Fourth, participants for the study were all recruited within state-maintained schools within the UK. Future research would be well advised to replicate this study both within Muslim independent schools within the UK, and within other cultural contexts.

Author Contributions: L.J.F. conceptualised the research question and analytical model. U.M. organised and documented the theoretical framework and undertook the data analysis. The paper was written jointly by both authors.

Acknowledgments: Young People's Attitudes to Religious Diversity Project (AHRC Reference: AH/G014035/1) was a large-scale mixed methods research project investigating the attitudes of 13- to 16-year-old students across the United Kingdom. Students from a variety of socio-economic, cultural, ethnic and religious backgrounds from different parts of England, Wales, Northern Ireland and Scotland, with the addition of London as a special case, took part in the study. Professor Robert Jackson was principal investigator and Professor Leslie J. Francis was co-investigator. Together they led a team of qualitative and quantitative researchers based in the Warwick Religions and Education Research Unit, within the Centre for Education Studies, University of Warwick. The project was part of the AHRC/ESRC Religion and Society Programme and ran from 2009-2012.

Conflicts of Interest: The authors declare no conflict of interest.

\section{References}

Allen, Chris. 2005. From race to religion: The new face of discrimination. In Muslim Britain: Communities under Pressure. Edited by Tahir Abbas. London: Zed Books, pp. 49-65.

Anwar, Muhammad. 2005. Issues, policy and practice. In Muslim Britain: Communities under Pressure. Edited by Tahir Abbas. London: Zed Books, pp. 31-46.

Anwar, Muhammad, and Firsila Shah. 2000. Muslim women and experiences of discrimination. In Multi-Level Discrimination of Muslim Women in Europe. Edited by Jochen Blaschke. Berlin: Edition Parabolis, pp. $203-48$.

Archer, Louise. 2003. Race Masculinity and Schooling: Muslim Boys and Education. Maidenhead: Open University Press.

Archer, Louise. 2012. Race, 'face' and masculinity: The identities and local geographies of Muslim boys. In Muslims in Britain: Race Place and Identities. Edited by Peter Hopkins and Richard Gale. Edinburgh: Edinburgh University Press, pp. 74-91.

Argyle, Michael. 1958. Religious Behaviour. London: Routledge and Kegan Paul.

Astley, Jeff, Leslie J. Francis, and Mandy Robbins. 2012. Assessing attitude towards religion: The Astley-Francis Scale of Attitude toward Theistic Belief. British Journal of Religious Education 34: 183-93. [CrossRef]

Beit-Hallahmi, Benjamin, and Michael Argyle. 1997. The Psychology of Religious Behaviour, Belief and Experience. London: Routledge.

Boulton, Michael. 1995. Patterns of bully/victim problems in mixed race groups of children. Social Development 4 : 277-93. [CrossRef]

Bowlby, Sophie, and Sally Lloyd-Evans. 2012. 'You seem very westernised to me': Place, identity and othering of Muslim workers in the UK labour market. In Muslims in Britain: Race Place and Identities. Edited by Peter Hopkins and Richard Gale. Edinburgh: Edinburgh University Press, pp. 37-54.

Brown, Laurence Binet. 1994. The Human Side of Prayer: The Psychology of Praying. Birmingham: Religious Education Press.

Costa, Paul T., and Robert R. McCrae. 1985. The NEO Personality Inventory Manual. Odessa: Psychological Assessment Resources.

Cronbach, Lee J. 1951. Coefficient alpha and the internal structure of tests. Psychometrika 16: 297-334. [CrossRef] 
De Bolle, Marleen, and Jennifer L. Tackett. 2013. Anchoring bullying and victimisation in children within a five-factor model-based person-centred framework. European Journal of Personality 27: 280-89. [CrossRef]

DeVellis, Robert F. 2003. Scale Development: Theory and Applications. London: Sage.

Eslea, Mike, and Kafeela Mukhtar. 2000. Bullying and racism among Asian schoolchildren in Britain. Educational Research 42: 207-17. [CrossRef]

Eysenck, Hans Jurgen, and Sybil B. G. Eysenck. 1975. Manual of the Eysenck Personality Questionnaire (Adult and Junior). London: Hodder and Stoughton.

Eysenck, Hans Jurgen, and Sybil B. G. Eysenck. 1991. Manual of the Eysenck Personality Scales. London: Hodder and Stoughton.

Eysenck, Sybil B. G., Hans Jurgen Eysenck, and Paul Barrett. 1985. A revised version of the psychoticism scale. Personality and Individual Differences 6: 21-29. [CrossRef]

Francis, Leslie J. 1978. Measurement reapplied: Research into the child's attitude towards religion. British Journal of Religious Education 1: 45-51. [CrossRef]

Francis, Leslie J. 1992. Is psychoticism really a dimension of personality fundamental to religiosity? Personality and Individual Differences 13: 645-52. [CrossRef]

Francis, Leslie J. 1996. The development of an abbreviated form of the Revised Junior Eysenck Personality Questionnaire (JEPQR-A) among 13- to 15-year-olds. Personality and Individual Differences 21: 835-44. [CrossRef]

Francis, Leslie J. 1997. The psychology of gender differences in religion: A review of empirical research. Religion 27: 81-96. [CrossRef]

Francis, Leslie J. 2000. The relationship between bible reading and purpose in life among 13-15 year olds. Mental Health, Religion and Culture 3: 27-36. [CrossRef]

Francis, Leslie J. 2001. The Values Debate: A Voice from the Pupils. London: Woburn Press.

Francis, Leslie J. 2002. The relationship between bible reading and attitude toward substance use among 13- to 15-year-olds. Religious Education 97: 44-60. [CrossRef]

Francis, Leslie J. 2003. Religion and social capital: The flaw in the 2001 census in England and Wales. In Public Faith: The State of Religious Belief and Practice in Britain. Edited by Paul Avis. London: SPCK, pp. 45-64.

Francis, Leslie J. 2008a. Religion as a persisting predictor of cultural diversity in the UK. In Europe: Secular or Post-Secular. Edited by Hans-Georg Ziebertz and Ulrich Riegel. Münster: Lit Verlat, pp. 167-90.

Francis, Leslie J. 2008b. Self-assigned religious affiliation: A study among adolescents in England and Wales. In Religion, Spirituality and the Social Sciences: Challenging Marginalisation. Edited by Basia Spalek and Alia Imtoual. Bristol: Policy Press, pp. 149-61. [CrossRef]

Francis, Leslie J. 2009. Understanding the attitudinal dimensions of religion and spirituality. In International Handbook of Education for Spirituality, Care and Wellbeing. Edited by Marian de Souza, Leslie J. Francis, James O'Higgins-Norman and Daniel Scott. International Handbooks of Religion and Education 3. Dordrecht: Springer Science, pp. 147-67. [CrossRef]

Francis, Leslie J., and Jeff Astley, eds. 2001. Psychological Perspectives on Prayer: A Reader. Leominster: Gracewing.

Francis, Leslie J., and Chris Hermans. 2009. Psychological health and attitude toward Christianity: A study among pupils attending Catholic schools in the Netherlands. Journal of Religious Education 57: 47-58.

Francis, Leslie J., and Susan H. Jones. 1994. The relationship between Eysenck's personality factors and fear of bullying among 13-15 year olds in England and Wales. Evaluation and Research in Education 8: 111-18. [CrossRef]

Francis, Leslie J., and Gemma Penny. 2014. Gender differences in religion. In Religion, Personality and Social Behaviour. Edited by Vassilis Saroglon. New York: Psychology Press, pp. 191-209.

Francis, Leslie J., and Gemma Penny. 2016. Prayer, personality and purpose in life: An empirical enquiry among adolescents in the UK. Research in the Social Scientific Study of Religion 27: 192-209.

Francis, Leslie J., and Andrew Village. 2014. Church schools preparing adolescents for living in a religiously diverse society: An empirical enquiry in England and Wales. Religious Education 109: 264-83. [CrossRef]

Francis, Leslie J., and Andrew Village. 2015. Assessing outgroup prejudice among 13- to 15-year-old students attending Catholic and Protestant secondary schools in Northern Ireland: An empirical enquiry. Irish Educational Studies 34: 265-79. [CrossRef] 
Francis, Leslie J., Harry Gibson, and David W. Lankshear. 1991. The influence of Protestant Sunday Schools on attitude towards Christianity among 11-15 year olds in Scotland. British Journal of Religious Education 14: 35-42. [CrossRef]

Francis, Leslie J., Mandy Robbins, Tania ap Siôn, Christopher Alan Lewis, and L. Philip Barnes. 2007. Psychological health and attitude toward Christianity among Protestant and Catholic sixth-form pupils in Northern Ireland. Pastoral Psychology 56: 157-64. [CrossRef]

Francis, Leslie J., Mandy Robbins, Christopher Alan Lewis, and L. Philip Barnes. 2008. Prayer and psychological health: A study among sixth-form pupils attending Catholic and Protestant schools in Northern Ireland. Mental Health, Religion and Culture 11: 85-92. [CrossRef]

Francis, Leslie J., Jennifer Croft, and Alice Pyke. 2012a. Religious diversity, empathy and God images: Perspectives from the psychology of religion and empirical theology shaping a study among adolescents in the UK. Journal of Beliefs and Values 33: 293-307. [CrossRef]

Francis, Leslie J., Jennifer Croft, Alice Pyke, and Mandy Robbins. 2012b. Young people's attitudes to religious diversity: Quantitative approaches from social psychology and empirical theology. Journal of Beliefs and Values 33: 279-92. [CrossRef]

Francis, Leslie J., Gemma Penny, and Alice Pyke. 2013. Young atheists' attitudes toward religious diversity: A study among 13- to 15-year-old males in the UK. Theo-web: Zeitschrift für Religionspädagogik 12: 57-78.

Francis, Leslie J., Tania ap Siôn, and Gemma Penny. 2014a. Is belief in God a matter of public concern in contemporary Wales? An empirical enquiry concerning religious diversity among 13- to 15-year-old males. Contemporary Wales 27: 40-57.

Francis, Leslie J., Andrew Village, Gemma Penny, and Peter Neil. 2014b. Catholic schools and attitudes toward religious diversity: An empirical enquiry among 13- to 15-year-old students in Scotland. Scottish Educational Review 46: 36-53.

Francis, Leslie J., Alice Pyke, and Gemma Penny. 2015. Christian affiliation, Christian practice, and attitudes to religious diversity: A quantitative analysis among 13- to 15-year-old female students in the UK. Journal of Contemporary Religion 30: 249-63. [CrossRef]

Francis, Leslie J., Tanis ap Siôn, Ursula McKenna, and Gemma Penny. 2017. Does religious education as an examination subject work to promote community cohesion? An empirical enquiry among 14- to 15-year-old adolescents in England and Wales. British Journal of Religious Education 39: 303-16. [CrossRef]

Gill, Robin. 1999. Churchgoing and Christian Ethics. Cambridge: Cambridge University Press.

Hodges, Ernest V. E., and David G. Perry. 1999. Personal and interpersonal antecedents and consequences of victimisation by peers. Journal of Personality and Social Psychology 76: 677-85. [CrossRef] [PubMed]

Hopkins, Adrienne, and Kirit Patel. 2006. Reflecting on gender equality in Muslim contexts in Oxfam GB. Gender and Development 14: 423-35. [CrossRef]

Jeory, Ted. 2016. UK Entering 'Unchartered Territory' of Islamophobia after Brexit Vote. The Independent. June 27. Available online: http:/ / www.independent.co.uk/news/uk/home-news/brexit-muslim-racismhate-crime-islamophobia-eu-referendum-leave-latest-a7106326.html (accessed on 20 September 2016).

Kay, William K., and Leslie J. Francis. 1996. Drift from the Churches: Attitude toward Christianity during Childhood and Adolescence. Cardiff: University of Wales Press.

Kodžopeljić, Jasmina, Snežana Smederevac, Dušanka Mitrović, Bojana Dinić, and Petar Čolović. 2014. School bullying in adolescence and personality traits: A person-centered approach. Journal of Interpersonal Violence 29: 736-57. [CrossRef] [PubMed]

Milam, Alex C., Christiane Spitzmueller, and Lisa M. Penney. 2009. Investigating individual differences among targets of workplace incivility. Journal of Occupational Health Psychology 14: 58-69. [CrossRef] [PubMed]

Milmo, Cahal. 2015. British Muslim school children suffering a backlash of abuse following Paris attacks. The Independent. January 23. Available online: http:/ / www.independent.co.uk/news/education/educationnews/british-muslim-school-children-suffering-a-backlash-of-abuse-following-paris-attacks-9999393. html (accessed on 20 September 2016).

Mitsopoulou, Effrosyni, and Theodores Giovazolias. 2015. Personality traits, empathy and bullying behavior: A meta-analytic approach. Aggression and Violent Behavior 21: 61-72. [CrossRef]

Modood, Tariq. 2012. Muslims and the politics of difference. In Muslims in Britain: Race Place and Identities. Edited by Peter Hopkins and Richard Gale. Edinburgh: Edinburgh University Press, pp. 193-209. 
Mynard, Helen, and Stephen Joseph. 1997. Bully/victim problems and their association with Eysenck's personality dimensions in 8 to 13 year-olds. British Journal of Educational Psychology 67: 51-54. [CrossRef] [PubMed]

Nielsen, Morten Birkland, and Stein Knardahl. 2015. Is workplace bullying related to the personality traits of victims? A two-year prospective study. Work and Stress 29: 128-49. [CrossRef]

NSPCC/Childline. 2013. Can I Tell You Something? What's Affecting Children in 2013. Childline Review of 2012/13. Available online: https:/ / www.nspcc.org.uk/globalassets/documents/research-reports/childlinereview-2012-2013.pdf (accessed on 26 September 2016).

Qurashi, Fahid. 2016. Prevent gives people permission to hate Muslims: It has no place in schools. The Guardian. April 4. Available online: https://www.theguardian.com/commentisfree/2016/apr/04/prevent-hatemuslims-schools-terrorism-teachers-reject (accessed on 20 September 2016).

Rattansi, Ali. 1992. Changing the subject? Racism, culture and education. In Race, Culture and Difference. Edited by James Donald and Ali Rattansi. London: Sage, pp. 11-48.

Runnymede Trust. 1997. Islamophobia: A Challenge for Us All. London: Runnymede Trust, For updated version. Available online: https:/ / www.runnymedetrust.org/uploads/Islamophobia\%20Report\%202018\%20FINAL. pdf (accessed on 7 August 2018).

Slee, Phillip T., and Ken Rigby. 1993. The relationship of Eysenck's personality factors and self-esteem to bully-victim behaviour in Australian schoolboys. Personality and Individual Differences 14: 371-73. [CrossRef]

Spilka, Bernard, and Kevin L. Ladd. 2013. The Psychology of Prayer: A Scientific Approach. New York: Guilford Press.

Tani, France, Paul S. Greenman, Barry Schneider, and Manuela Fregoso. 2003. Bullying and the Big Five: A study of childhood personality and participant role in bullying incidents. School Psychology International 24: 131-46. [CrossRef]

Verma, Gajendra, Paul Zec, and George Skinner. 1994. The Ethnic Crucible: Harmony and Hostility in Multi-Ethnic Schools. London: Falmer Press.

Vertovec, Steven. 2002. Islamophobia and Muslim recognition in Britain. In Muslims in the West: From Sojourners to Citizens. Edited by Yvonne Haddad. Oxford: Oxford University Press, pp. 19-35. [CrossRef]

Weller, Paul A., Feldman Alice, and Purdam Kingsley. 2001. Religious Discrimination in England and Wales. London: Home Office.

(c) 2018 by the authors. Licensee MDPI, Basel, Switzerland. This article is an open access article distributed under the terms and conditions of the Creative Commons Attribution (CC BY) license (http://creativecommons.org/licenses/by/4.0/). 